\title{
Do Managerial Ability Impact Indonesian Firm Risk-Taking Behavior?
}

\author{
Emiliya Rahma Wati ${ }^{1, a *}$, Heru Tjaraka ${ }^{1, b}$, Erina Sudaryati ${ }^{1, c}$ \\ ${ }^{1}$ Accounting Departement, Faculty of Economics \& Business, Universitas Airlangga \\ Jl. Airlangga No.4, Airlangga, Surabaya, East Java, Indonesia \\ e-mail: ${ }^{\text {a* }}$ emiliya.rahma.w-2018@feb.unair.ac.id, ${ }^{b}$ heru-t@feb.unair.ac.id, ${ }^{c}$ erina.sudaryati@ feb.unair.ac.id \\ * Corresponding Author
}

\begin{abstract}
This study aims to examine the role of managerial in firm decisions. This study recognizes that managerial plays an important role in corporate decision making. Decisions carried out by the company are not only influenced by the manager's explicit mandate to maximize firm value, but also by the manager's ability to manage the company. In previous research it was found that highability and low-ability managers have opposite effects on firm behavior and firm value. Highability managers accept risk-taking whereas low-ability managers refrain from taking risks. Managerial Ability in this study was measured using DEA (Data Envelopment Analysis) while for firm risk-taking behavior using the return on assets (ROA), return on equity (ROE), and research and development costs to total assets $(R \& D)$. The model used in this study is a causality model or the relationship of influence between research variables. The proposed model is analyzed using the Structural Equation Model (SEM) causality technique. This research was conducted on manufacturing companies listed on IDX (Indonesian Stock Exchange) in 2013-2017. However, unlike previous studies, the results of this study indicate that highly capable managers play a role in minimizing corporate risk taking. This research contributes as a reference for Indonesian corporate investors and also regulators as a reflection of the effectiveness of regulations made in Indonesia.
\end{abstract}

Keywords: Firm Risk, Managerial Ability, Risk Taking

Article History: Received: June, 152020 Revised: September, 262020 Accepted: October, 92020

How to cite: Wati, E. R., Tjaraka, H., \& Sudaryati, E (2020). Do Managerial Ability Impact Indonesian Firm Risk-Taking Behavior?. Akrual: Jurnal Akuntansi, 12(1):18-.33

DOI: https://doi.org/10.26740/jaj.v12n1.p18-33

\section{INTRODUCTION}

In the development of this globalization era, competition in the business environment is becoming increasingly competitive. So, it is necessary to have the right strategy for the company in facing the risks that will affect the sustainability of the company. Responding to this, the company needs management as company managers with high capabilities.

Managerial ability is an ability that management has in managing the company. The traditional issue related to managerial ability assumes that company managers behave rationally and follow the mandate given by maximizing firm value. Managerial heterogeneity is considered unlikely to have a significant role in firm decisions (Berk and Stanton, 2007). 
Demerjiand et al. (2013) explained that managerial ability includes the ability of managers to take and implement decisions that can lead the company to a high level of efficiency. Efficiency refers to the minimum use of resources to achieve optimum results. Therefore, efficiency implies the existence of management decisions to achieve company goals by using optimal methods.

Recent research related to managerial ability is able to prove that management attributes are an important determinant of corporate behavior (Graham et al, 2012). Berk \& Stanton (2007) stated that managerial heterogeneity has a significant influence on corporate decision making. The desire of managers is in line with the desire for company profit so they improve company performance.

Chen, (2018) in his research revealed that managers with high abilities accept risk taking in running a company, while managers with low abilities try to refrain from taking these risks. Corporate risk taking is the basis for a company's survival. Previous research suggests that managers' decision to take risks in pursuit of profitable opportunities is a fundamental driving force of company performance and growth (Bromiley 1991; John et Johnal. 2008). Other research also proves that risk taking is an important element of managerial roles (March and Shapira 1987).

The motivation for this research is the first that company management often adopts policies that are deliberately designed for the efficiency of the company, which might pose a big risk to the company. Previous research has not always been consistent either to describe managerial ability conditions associated with company risk, or to empirical measures used to link the two conditions. So that in this study it is expected to be able to clarify the relationship between managerial ability and the willingness of management to take risks on these decisions.

The effect of managerial ability on firm-risk taking behavior has been previously studied by Chen (2018). In his research, Chen (2018) emphasizes the importance of the role of managers for the results achieved by the company. Managerial ability has a significant impact on the quality of company's earnings (Demerjian et al, 2012; Choi et al 2015). Second, this research is expected to be useful for deepening knowledge and application of upper echelon theory, especially for analyzing the outcomes of policies taken by top management related to corporate risk taking.

In the future, it is hoped that this research will be beneficial as a reference for research on managerial ability and its effect on firm risk-taking, both developed by qualitative and quantitative research methods. The variable of managerial ability is important in this study because it is expected that with high managerial ability, managers more consider the cost and benefits of taking firm risk because it will also have an impact on company's outcomes.

This research hopefully contributed to investment activities in Indonesia where the investors need to acquire firm risk-taking patterns into consideration, so that the company 
is suitable for investment activities. This research is also hopefully contributed to the government as a regulator to reflection of the effectiveness of ongoing regulations.

\section{Upper Echelons Theory}

Upper echelons theory considers the concept of top management as the main strategic decision maker in the organization. Thus, the strategic decisions that leaders make have a direct impact on organizational outcomes. Because executives have responsibility for the organization as a whole, their characteristics, what they do, and how they do it, specifically affect organizational outcomes (Finkelstein, Hambrick, \& Cannella, 1996). The leadership of a complex organization is the division of tasks, shared awareness, skills, and interactions with all members of top management to lead to strategic behavior (Finkelstein et al., 1996). The leader plays an important role in strategic decision making and resource allocation. Hambrick and Mason (1984) through Upper Echelon Theory, state that the strategy chosen by the leader is a reflection or a reflection of their values and cognitive.

Upper Echelons Theory is better known as managerial concepts (Hambrick \& Finkelstein, 1987). However, DiMaggio \& Powel (1983) introduced a new institutional concept. Executives can also be little influence because they are formed by a number of conventions and norms that govern business processes and the corporate environment.

Most recently Hambrick, Finkelstein \& Mooney (2005) introduced moderators from Upper Echelons namely: executive work demands. Although in general the CEO carries a very heavy burden with great pressure, in some cases the work of the upper echelons can differ from one another. There are several CEOs who work in a relatively safe environment, and are supported by strategic position and have capable subordinates, but there are CEOs who do not have this condition. These executive job demands can come from 3 factors, namely task challenges, performance challenges, and also aspirations that contain their personal desire to provide maximum performance for the company. In accordance with the reform of the upper echelon theory (Hambrick, 2007), how organizations behave will be largely determined by the character of this upper executive.

\section{Agency Theory}

Agency theory or agency theory describes the relationship between shareholders as the principal and management as the agent. Management is a party contracted by shareholders to work for the interests of shareholders. Because they were elected, management had to account for all of its work to shareholders (Jensen \& Meckling, 1976a).

An important issue in a supervisory system is the problem of agency relations which is described by Jensen and Meckling (1976a) as a contract between one or more parties (as principal) and other parties (as agents), to exercise authority and decision-making on behalf of the principal. The concept of agency theory according to Anthony and Govindarajan (1995) is a relationship or contract between the principal and the agent. Principals employ agents to perform tasks in the interests of the principal, including 
delegating decision-making authority from the principal to the agent. There are two types of agency problems, namely Adverse selection and Moral Hazard. In agency theory, agents tend to be selfish in allocating investments, from those that do not increase firm value to more profitable investment alternatives.

\section{Risk Management Theory}

Padovani (2004) explains the importance of risk management discipline today. First, the increasing volatility and competition that companies have to face at this time, forces companies to apply at least some level of risk awareness. It is also linked to some very well-known international scandals such as the Enron case, WorldCom and more recently the Lehman Brothers. Organizations generally face legal requirements by authorities and regulators, which require the adoption of increasingly sophisticated risk management practices. In addition, because technology has helped organizations to become more efficient, it exposes companies to significant new types of threats. As claimed by Padovani (2004) the elements described have created new risks and increased the impact and frequency of existing risks. Therefore, the modern recognition of risk management as a process that complements and integrates with other processes within a company, in an ongoing and formal manner, may be an approach that is relevant to the reality facing the entity. In this case, the risk management process becomes not only an instrument to prevent and manage the impact of events that give rise to risk in the company, but also the power to see opportunities that exist within the company (Padovani, 2004).

\section{Managerial Ability}

Managerial ability is a management characteristic such as talent, quality, ability, and management reputation, where these actions also affect the company's decision making. Managerial ability research has been carried out, such as research by Bertrand and Schoar (2003) where the significance level of heterogeneity in investment, finance, and corporate organizational practices is influenced by the fixed effect of managers.

Managerial ability is proven to have a high mediating effect in facilitating the relationship between the capacity of the company and the risk management that can be done by management (Andreou, Philip, \& Robejsek, 2016). This is in line with research conducted by B. Francis, Sun, and Wu (2013) which shows that companies with higher managerial abilities get more favorable loan contract terms, such as low loan spreads, less tight agreements, and falling long term.

As an agent, managers must have the skills to be able to manage the company well. Some explanations about a capable manager include:

1. A capable manager is a manager who has extensive knowledge of the company's business, so that he is able to make better judgments and estimates (PR Demerjian et al., 2013). 
2. Capable managers generate high returns through profitable investment opportunities (Wei, 2007).

3. A capable manager is able to create value from the use of resources controlled by the company (Holcomb, Holmes Jr, \& Connelly, 2009).

\section{Firm risk-taking}

Firm Risk or company risk is a condition of financial uncertainty faced by a company so that it has an impact on investors who hold securities in certain companies. These conditions can be referred to as company-specific risks, unsystematic risks, or diversifiable risks. Company risk can be reduced through investment strategies such as diversification and purchasing of uncorrelated securities or assets (www.investopedia.com).

There are many types of company-specific risks that can affect a company's profit potential or even its solvency. These types of risk can include things like changes to regulations by the government that could hurt the company. The following are the risks the company has financial risk financial; marketing risk marketing; operational risk operational; strategic risk strategic; legal risk.

The effect of managerial ability on firm risk-taking behavior has been previously studied (Yung \& Chen, 2018). In their research, Yung and Chen (2018) emphasizes the importance of the role of managers for the results achieved by the company. Managerial ability has a significant impact on the quality of company earnings (PR Demerjian et al., 2013). Upper echelon theory is the basis for the construction of managerial ability on firm risk-taking behavior. Upper echelon theory explained that the top management as a major strategics decision makers within the organization while taking the risk of the company is an outcomes strategic decision of the manager.

Previous studies have also shown a positive influence between managerial ability and firm risk-taking behavior. For example, Cremers and Petajisto (2009) in their research show that skilled investment managers are also active managers who can make risky investment decisions that excel in the investment industry. Chemmanur, Paeglis, and Simonyan (2009) found that managers with better reputations and managers with higher quality were able to choose better projects. The study argues that firms with better managers tend to have larger scales of investment balances. Thus, it is possible that capable managers are more willing to take risks in firm decisions. Consistent with this view, Y. Chen, Podolski, and Veeraraghavan (2015) and Andreou et al. (2016) found that capable managers are more likely to pursue risk-taking activities for firms.

Based on studies from several literature and also previous research, the conceptual framework for the research model proposed in this study can be described as follows: 


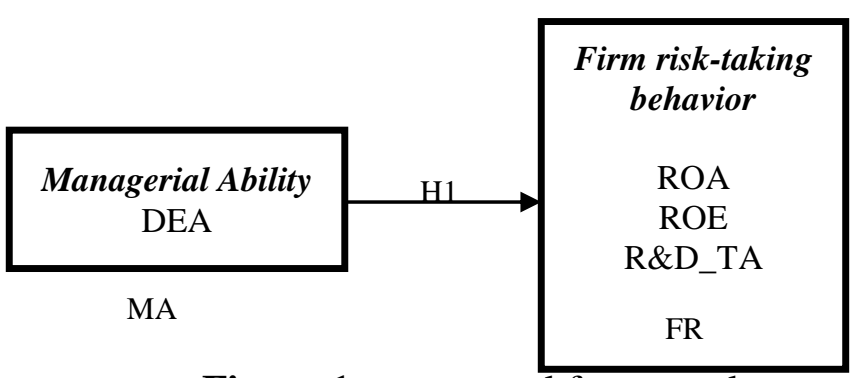

Figure 1: conceptual framework

This study wants to further confirm the role of the ability of management in making company decisions as a risk-taking step to increase the profits that the company gets. Based on this explanation, hypothesis 1 proposed in this study is:

H1: High managerial ability has an effect on increasing (decreasing) firm-risk taking behavior.

\section{RESEARCH METHOD}

This study uses secondary data. The data processed from company financial reports obtained from IDX (Indonesian Stock Exchange) (https://www.idx.co.id). The population in this study were all manufacturing companies listed on the IDX in 2013-2017. The research sample is all manufacturing companies that have both negative and positive profits throughout 2013-2017 and have reported their financial reports on the IDX which produced as many as 1100 units of analysis.

The research was conducted in the manufacturing sector company. The selection of the manufacturing sector is based on the scale of the manufacturing sector in Indonesia. Indonesia has become the largest manufacturing industry base in ASEAN, contributing $20.27 \%$ to the national economy. The development of the manufacturing industry in Indonesia is currently able to shift the role of commodity based to manufacture based. The government is trying to transform the economy to focus more on the process of developing the non-oil and gas industry (www.investindonesia.go.id).

The manufacturing industry is considered to be more productive and can have a broad chain effect so as to increase the added value of raw materials, increase the workforce, generate the largest source of foreign exchange, and the largest tax and customs contributor. The characteristics of manufacturing companies that have complex operational processes and various kinds of cost items are also a consideration for the choice of the manufacturing sector in this study. Concerning the field of taxation, postage costs are considered easy for companies to manipulate. Research \& Development is also often carried out by manufacturing companies. This is interesting for the author to examine related managerial abilities and their effect on tax aggressiveness and corporate risk-taking as well as the presence of good corporate governance as a mediating variable in 
manufacturing companies listed on the IDX. Given the contribution of manufacturing companies to national GDP has a great value.

\section{Research Variables and Operational Definitions}

Managerial Ability (MA)

Managerial Ability are measured using Data Envelopment Analysis (DEA). DEA is an optimization program used to process the relative terms of an Economic Activity Unit (UKE) in the form of a comparison between output or multi-output with input or multiinput. The results of the comparison between one UKE can be compared in efficiency with another UKE with the same output and input conditions.

Managerial ability in this study is defined as relative efficiency level of a company in managing inputs (resource and operational factors) to increase output (sales). The score is obtained to assess the manager. The input used in this study use the input by Isnugrahadi and Kusuma (2009), namely:

a. Cost of Goods Sold (COGS) is a cost that directly contributed to sales. (Demerjian, 2013).

b. Selling, General, and Administrative Cost (SGA), indirectly affects sales because it includes management compensation, general office running costs and other costs to support sales. Sales may not be effective without the absence of this SGA (Demerjian, 2013).

c. Property, Plant, and Equipment (PPE), was an investments decision taken by management. The company will be more efficient if it can generate sales in the same amount as other companies but with a smaller amount of investment (Demerjian, 2013).

d. Intangible Asset, was an asset closely related to human resources including human capital assets, knowledge and creativity, and brand assets.

Those inputs are an important component in the company's operations in producing the expected output.

Output, Output, the output used is only one, namely sales. Sales are used as output because sales represent the nominal value of the company's products, which are the company's basic output.

To measure managerial ability, the following formula is used:

$$
M A=\frac{\text { Output }(\text { sales })}{\operatorname{Input}(\text { COGS }+S G A+P P E+I N T A N)}
$$

The results of these calculations are then described as the managerial ability. 
Firm Risk-Taking Behavior (FR)

In this study, to measure risk-taking behavior is measured using the return on assets (ROA), return on equity (ROE), research and development costs to total assets (R\&D) with the following formula:

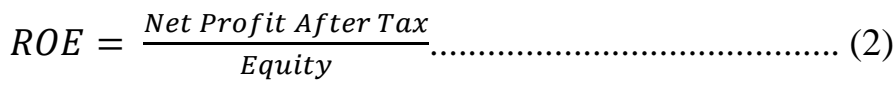

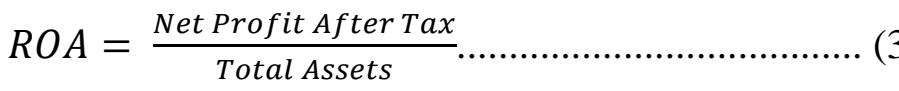

$$
\begin{aligned}
& R \& D=\frac{\text { Research \& Development }}{\text { Total Assets }}
\end{aligned}
$$

The model used in this study is a causality model or the relationship of influence between research variables. To test the proposed model used Structural Equation Model (SEM) causality analysis technique based on component or variance or better known as the Partial Least Square (PLS) model.

Outer Model Measurements

In the partial least square analysis technique, the measurement of the outer model and inner model is used in testing activities. In this study, the measurement of the outer model was used with the loading factor value of each indicator. A reflective measure is said to be high if it correlates more than 0.7 with the construct to be measured. According to Chin (1998) in Yamin and Kurniawan (2011: 18) for research. The initial stage of developing a measurement scale for the outer loading value of 0.5 to 0.60 is considered sufficient. In this study, an outer loading value of 0.5 was used.

\section{Inner Model Measurement}

The tests and measurements that have been described are the forms of measuring the outer model. After the measurement of the outer model has been completed, the inner model is measured. Inner model measurement is done to determine the level of influence of the relationship between variables, as well as the level of influence of the relationship between all variables in the system being built. The inner model measurement to test the relationship between variables in the study used the R-Square (R2) value. Meanwhile, the relationship between variables in the system built in the study was calculated using the predictive-relevance (Q2) value (Yamin and Kurniawan, 2011: 124). The predictiverelevance $(\mathrm{Q} 2)$ value is a value obtained from the R-Square (R2) value of each variable.

\section{Hypothesis testing}

Based on the research objectives, the hypothesis test design made is a hypothesis test design which in this study is presented based on the research objectives, namely the $t$ hypothesis test to assess the effect of independent variables separately. The confidence level used is $95 \%$, so the level of precision or the limit of inaccuracy is $(\alpha)=5 \%$ with a table value of 1.976 . 
Table 1. Partial Least Square (PLS) assessment criteria

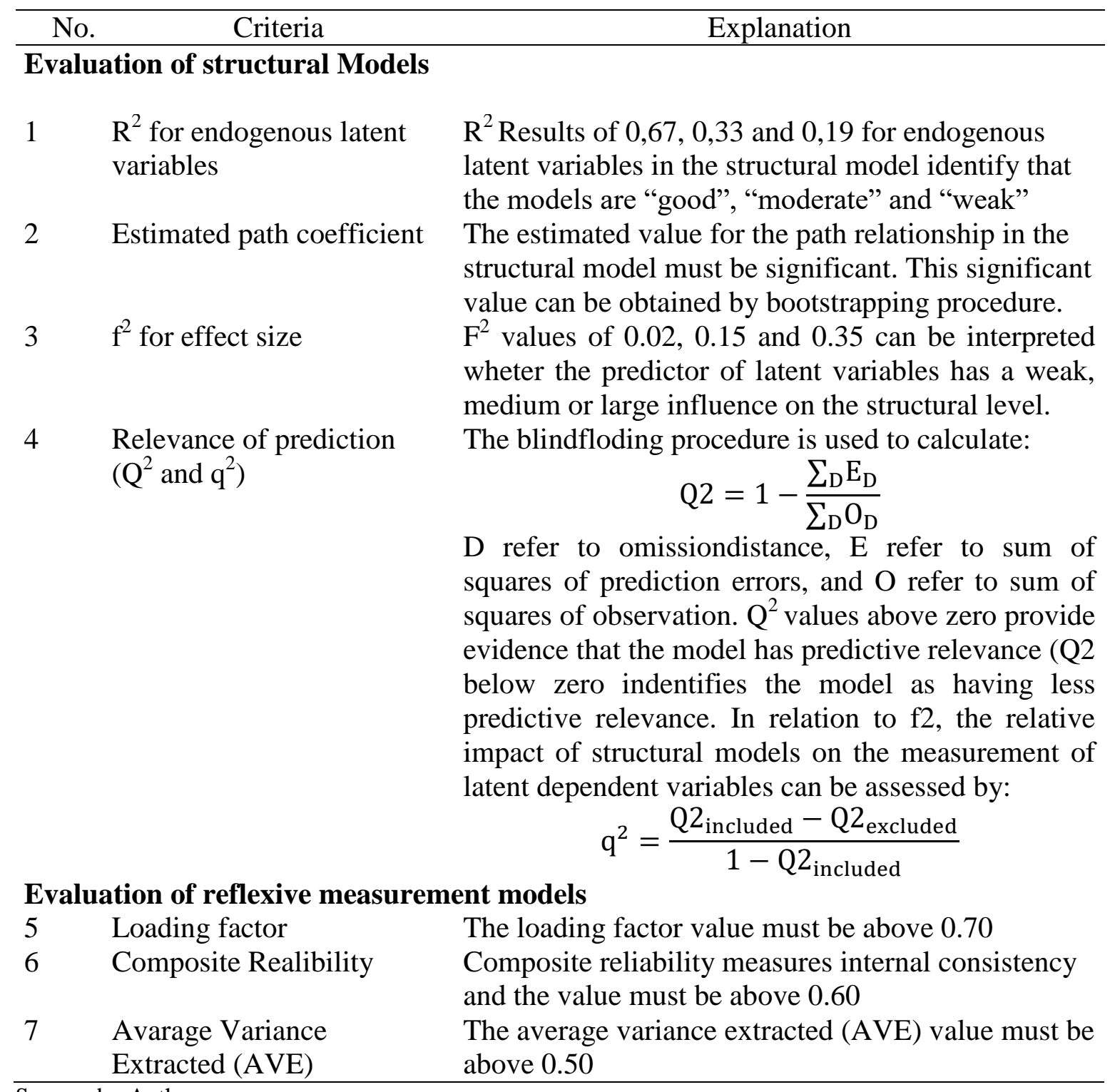

Source: by Author

\section{RESULTS AND DISCUSSION}

\section{Evaluasi Outer Model}

In the outer model, there is an analysis of the validity and reliability of the PLS indicators. The indicator validity consists of convergent validity and discriminant validity, while reliability can be seen from composite reliability.

An indicator is declared valid if it has a loading factor above 0.5 according to Imam Ghozali (2014: 39). To test the convergent validity, the outer loading or loading factor value is used. An indicator is declared to meet the convergent validity in the good category 
Wati, Tjaraka, \&Sudaryati, Do Managerial Ability Impact...

if it has a loading factor value> 0.50. The Smart PLS output for loading factors gives the following results:

Table 2. Validity Analysis (convergent validity)

\begin{tabular}{llll}
\hline Variabel & Indicator & Outer Loading & Information \\
\hline Firm-Risk Taking & R\&D & 0,042643 & Invalid \\
Behavior & ROA & 0,959105 & Valid \\
& ROE & 0,881158 & Valid \\
Managerial Ability & MA & 1,000000 & Valid
\end{tabular}

Source: primary data, 2020 processed PLS 2.0

Table above shows that the loading factor gives a value above the recommended value of 0.5 (Imam Ghozali, 2014: 40). However, there are still indicators that are less than the stipulated conditions, so it is necessary to re-test by issuing several indicators that do not meet the requirements. Here are the results of loading factors after several indicators that are less than the requirements are issued, so:

Table 3. Validity test (convergent validity)

\begin{tabular}{llll}
\hline Variabel & Indicator & Outer Loading & Information \\
\hline Firm-Risk Taking & ROA & 0,959105 & Valid \\
Behavior & ROE & 0,881158 & Valid \\
Managerial Ability & MA & 1,000000 & Valid \\
\hline
\end{tabular}

Source: primary data, 2020 processed PLS 2.0

The table above shows that the loading factor gives a value above the recommended value of 0.5 (Imam Ghozali, 2014: 40). This means that the indicators used in this study are valid or have met Convergent Validity.

For the discriminant validity stage, the measurement is assessed based on the cross loading of the measurement with the construct or by comparing the AVE root for each construct with the correlation between one construct and another in the model. A model is said to have sufficient discriminant validity if the AVE root for each construct is greater than the correlation between the constructs and the other constructs in the model. The following table shows the AVE values and AVE roots. 
Table 4. AVE

\begin{tabular}{ll}
\hline Variabel & Indicator \\
\hline Firm-Risk Taking Behavior & 0.848185 \\
Managerial Ability & 1.000000
\end{tabular}

Source: primary data, 2020 processed PLS 2.0

Apart from comparing the AVE root value with the latent variable correlation, the discriminant validity test can also be done by looking at the cross loading value. The criterion in cross loading is that every indicator that measures its construct must have a higher correlation with the construct than other constructs. In the loading score table, it will be seen that each indicator in a construct will be different from the indicator in other constructs and collect on the intended construct. It can be seen in the following table:

Tabel 5. Cross Loading

\begin{tabular}{lll}
\hline Variabel & Firm risk-taking behvior & Managerial ability \\
\hline MA & -0.148146 & $\mathbf{1 . 0 0 0 0 0 0}$ \\
ROA & $\mathbf{0 . 9 5 9 1 0 0}$ & $-0,162128$ \\
ROE & $\mathbf{0 . 8 8 1 1 9 1}$ & $-0,097075$
\end{tabular}

Source: primary data, 2020 processed PLS 2.0

The variables used in this study, namely managerial ability and firm risk-taking behavior have met the criteria in cross loading. The criteria that apply in cross loading are that each indicator measuring its construct must have a higher correlation with the construct than the correlation with other constructs (Jogiyanto, 2011). From the crossloading results of Smart PLS processing, it can be seen that all the variables used have met the requirements where each indicator measuring the construct has a higher correlation with the construct than the correlation with other constructs.

Reliability test is needed to measure the stability and consistency of an instrument in measuring a concept or variable. In this study, reliability can be measured by looking at the composite reliability value. Salisbury et al in Jogiyanto (2011) states that composite reliability measures the real value of the reliability of a construct. On the table. It can be seen the amount of Cronbachs Alpha value, composite reliability.

Tabel 6. Composite Reliability

\begin{tabular}{lll}
\hline Variabel & Cronbachs Alpha & Composite Reliability \\
\hline Firm risk-taking behavior & 0.831317 & 0.917722 \\
Managerial ability & 1.000000 & 1.000000
\end{tabular}

Source: primary data, 2020 processed PLS 2.0 
Wati, Tjaraka, \&Sudaryati, Do Managerial Ability Impact...

The Cronbachs Alpha value for each construct is $>0.6$. This shows that the reliability for each indicator used in this study is feasible. For the value of composite reliability has a value of $>0.6$, therefore the variables in this study have good reliability.

\section{Inner Model Evaluation}

In PLS, the structural model is evaluated by calculating the Goodness of Fit (GoF). The reference in GoF measurement is described by Tenenhaus, et al. (2005) is to use the multiplication calculation between the average value of communalities and the average value of the R-square. GoF values ranged from $0-1$ with interpretations of 0.1 (small GoF), 0.25 (moderate GoF), 0.36 (large GoF). The following table shows the mean value of communalities and also the mean value of the R-square.

\section{Tabel 7. Evaluation result of Coefficient of Determination $\left(\mathbf{R}^{2}\right)$ and Communalities}

\begin{tabular}{lll}
\hline Variabel & R Square & Communality \\
\hline Firm risk-taking behavior & 0.021947 & 0.848185 \\
& & 1.000000 \\
Managerial ability & 0.2207795 & 0.136437
\end{tabular}

Source: primary data, 2020 processed PLS 2.0

From the table above, the calculation of the average value of communalities is 0.848185; while the average value of R-square is 0.021947 ; so GoF $=\sqrt{0.021947 \times 0.848185}=0.136437$ (small GoF). By looking at these results it can be concluded that the performance between the measurement model and structural model has a small GoF of 0.136437, this indicates that the combined performance of the measurement model and structural model is small.

\section{Hypothesis testing}

Further testing can be done by looking at the path coefficient value or inner model which shows the level of significance in testing the hypothesis. In terms of seeing the significance of the relationship between constructs, the T-test analysis of the path coefficient is used. The path relationship between these variables is considered significant if it has a $\mathrm{T}$ statistics of more than 1.96 .

Tabel 8. Evaluasi Path Coefficient and Signification test

\begin{tabular}{cccc}
\hline Hypothesis & Variabel & Path Coefficient & T Statistic \\
\hline H1 & $\begin{array}{c}\text { Managerial ability -> Firm risk-taking } \\
\text { behavior }\end{array}$ & -0.148146 & 5.566095 \\
\hline Source: primary & & \\
\hline
\end{tabular}

Source: primary data, 2020 processed PLS 2.0

In conducting hypothesis testing, it can be seen from the magnitude of the t-statistic value. The hypothesis is said to be accepted if the t-statistic value of the proposed hypothesis has a value of more than 1.96. However, if it does not meet these requirements, 
it can be said that the existing hypothesis is rejected. The t-statistic value can be seen in the path coefficient table (t-statistic) in the previous table.

Hypothesis 1 states that Managerial Ability affects Firm-Risk Taking Behavior. The results of calculations using Smart PLS 2.0 software show that the path variable Managerial Ability with Firm-Risk Taking Behavior has a negative effect with a beta coefficient value of -0.148146 and T-statistics of 5.566095, this means that hypothesis 1 is supported.

A series of test results show that high managerial ability decreased firm risk-taking behavior. Managers with high ability conservatively take action not to increase the company's risk-taking activity. Companies with high managerial ability are able to carry out efficient business activities where the output generated from the business process is almost the same as the input that has been given to the company. In fact, there are several companies has an efficiency value of more than 1 in Indonesia, namely DLTA where the output they produce far exceeds the input used to carry out the company's operational activities. however, not all companies have the same efficiency score. This indicates that company managers are able to reduce costs and cost of goods sold so that the output in the form of sales generated from these business activities was high.

The results of this study are in line with research conducted by Park et al (2016) using the managerial ability measure P. Demerjian et al. (2012) found a negative and significant relationship between managerial ability and tax avoidance. In this study, the manager actually has a role to take alternative steps to prevent tax avoidance. The study also found that the capital market reacted not as affected by tax sheltering news led by managers with high abilities than companies led by managers with low abilities. The results of this study draw the conclusion that managers with high abilities are not interested in the large cost savings from tax avoidance and consider these efforts to be actually costs incurred from tax avoidance activities. Managers with high abilities are better able to transform the company's revenue resources and spend more effort in normal business operations than are involved in tax evasion efforts. Tax avoidance here can also be interpreted as risk-taking by managers. However, it needs further research related to the concept of tax avoidance and firm risk taking.

$R \& D$ variable in this study used as a proxy for corporate risk-taking is not suitable to apply for Indonesia companies. This is due to the lack of disclosure of R\&D costs by companies. furthermore, the cost of $\mathrm{R} \& \mathrm{D}$ is only concentrated in several types of industries such as cement, textile and pharmaceutical industries. This could be influenced by the characteristics of these industries need continuous development to create products that suit to what the market actually needs.

High managerial ability is able to reduce the risk taking of manufacturing companies in Indonesia. These results can also provide support for the view that regulations related to corporations in Indonesia are well adapted and run by companies. Companies do not want 
to put investors in a risky position on the investment they have made by doing risk-taking actions. That condition remains companies in a stable condition.

Managers prefer to maximize their ability to make efficiency with existing business processes so that business processes tend to be efficient. Managers may squeeze the cost of goods manufactured in such a way and utilize the PPE at their disposal to produce products with optimal sales. Technological sophistication may also help managers minimize their production costs, so that managers no longer need to take risky actions to maximize company profits.

\section{CONCLUSION}

Based on data obtained from companies on the IDX in 2013-2017, researchers tested one hypothesis in this study. The results of the testing have been carried out, it can be concluded that the hypothesis is accepted, namely: High managerial ability has an effect on increasing firm-risk taking behavior. The direction of this research is negative, indicated by the path coefficient which is negative so that managerial ability has a negative effect in increasing the activity of firm risk-taking behavior.

This indicates that the role of managers in carrying out risk prevention in the company is done well. The position of the manager as the manager of the company is expected to be able to minimize the risk that the company accepts in terms of any decisions taken by the manager. By reducing the risk accepted by the company, it is hoped that the company will obtain maximum benefits and the trust of shareholders. This is important as a consideration for shareholders in investing their capital in the company.

This study can prove empirically that the role of managerial ability has a negative effect on firm-risk taking behavior, which means that the role managerial ability has of high effect on lower firm risk taking. This may also be the impact of the regulation strictness in Indonesia, such as OJK, so that companies with high managerial abilities play a conservative role in taking corporate risks.

This research will be beneficial as a reference for research on managerial ability and its effect on firm risk-taking, both developed by qualitative and quantitative research methods. The variable of managerial ability is important in this study because it is expected that with high managerial ability, managers more consider the cost and benefits of taking firm risk because it will also have an impact on company's outcomes.

The limitation in this study is that the data used in this study is limited to the year of 2013-2017 which was obtained from the IDX (Indonesian Stock Exchange) website. The addition of the research period will help the accuracy of the research data, so that balanced research results can be obtained. Future research can take some of the variables that have been tested in this study but in future studies the variables can be expanded by using other variables that also reflect a broader firm-risk taking behavior so that the results will be better. Considering that the variables used in this study are company R\&D, it turns out that 
disclosure of these variables is rarely done in companies in Indonesia that are listed on the IDX (Indonesian Stock Exchange).

\section{REFERENCES}

Andreou, P. C., Philip, D., \& Robejsek, P. (2016). Bank Liquidity Creation and RiskTaking: Does Managerial Ability Matter? Journal of Business Finance \& Accounting, 43(1-2), 226-259. doi:10.1111/jbfa.12169

Anthony, R. N., \& Govindarajan, V. (1995). Management Control Systems. Eight Edition International Student Edition. Richard D. Irwin Inc. U.S.A.

Berk, J. B., \& Stanton, R. (2007). Managerial Ability, Compensation, and the Closed-End Fund Discount. The Journal of Finance, 62(2), 529-556. doi:10.1111/j.15406261.2007.01216.x

Bertrand, M., \& Schoar, A. (2003). Managing with style: The effect of managers on firm policies. The Quarterly journal of economics, 118(4), 1169-1208. doi:10.1162/003355303322552775

Bloom, M., \& Milkovich, G. T. (1998). Relationships Among Risk, Incentive Pay, and Organizational Performance. Academy of Management Journal, 41(3), 283-297. doi:10.5465/256908

Bromiley, P. (1991). Testing a Causal Model of Corporate Risk Taking and Performance. Academy of Management Journal, 34(1), 37-59. doi:10.5465/256301

Chemmanur, T. J., Paeglis, I., \& Simonyan, K. (2009). Management quality, financial and investment policies, and asymmetric information. Journal of Financial and Quantitative Analysis, 1045-1079. doi:10.1017/s0022109009990299

Chen, Y., Podolski, E. J., \& Veeraraghavan, M. (2015). Does managerial ability facilitate corporate innovative success? Journal of empirical finance, 34, 313-326. doi:10.1016/j.jempfin.2015.08.002

Cremers, K. M., \& Petajisto, A. (2009). How active is your fund manager? A new measure that predicts performance. The review of financial studies, 22(9), 3329-3365. doi:10.2139/ssrn.891719

Demerjian, P., Lev, B., \& McVay, S. (2012). Quantifying managerial ability: A new measure and validity tests. Management science, 58(7), 1229-1248. doi:10.2139/ssrn.1266974

Demerjian, P. R., Lev, B., Lewis, M. F., \& McVay, S. E. (2013). Managerial ability and earnings quality. The accounting review, 88(2), 463-498. doi:10.2139/ssrn.1650309

Finkelstein, S., Hambrick, D., \& Cannella, A. A. (1996). Strategic leadership. St. Paul: West Educational Publishing.

Francis, B., Sun, X., \& Wu, Q. (2013). Managerial Ability and Tax Aggressiveness. Available at SSRN 2348695.

Hambrick, D. C., \& Mason, P. A. (1984). Upper echelons: The organization as a reflection of its top managers. Academy of management review, 9(2), 193-206. doi:10.5465/amr.1984.4277628

Holcomb, T. R., Holmes Jr, R. M., \& Connelly, B. L. (2009). Making the most of what you have: Managerial ability as a source of resource value creation. Strategic management journal, 30(5), 457-485. doi:10.1002/smj.747 
Wati, Tjaraka, \&Sudaryati, Do Managerial Ability Impact...

Isnugrahadi, I., \& Kusuma, I. W. (2009). Pengaruh Kecakapan Manajerial terhadap Manajemen Laba dengan Kualitas Auditor sebagai Variabel Pemoderasi. Universitas Gadjah Mada.

Jensen, M. C., \& Meckling, W. H. (1976a). Agency Costs and the Theory of the Firm. Journal of Financial Economics, 3(4), 305-360.

Jensen, M. C., \& Meckling, W. H. (1976b). Theory of the firm: Managerial behavior, agency costs and ownership structure. Journal of Financial Economics, 3(4), 305360.

Jogiyanto, H. (2010). Teori portofolio dan analisis investasi (edisi ketujuh). Yogyakarta: BPFE.

John, K., Litov, L., \& Yeung, B. (2008). Corporate governance and risk-taking. The Journal of finance, 63(4), 1679-1728.

March, J. G., \& Shapira, Z. (1987). Managerial perspectives on risk and risk taking. Management science, 33(11), 1404-1418. doi:10.1287/mnsc.33.11.1404

Padovani, R. (2004). L'enterprise risk management nelle imprese non finanziarie: aspetti teorici e studi di caso nel mercato italiano.

Park, J., Ko, C. Y., Jung, H., \& Lee, Y.-S. (2016). Managerial ability and tax avoidance: evidence from Korea. Asia-Pacific Journal of Accounting \& Economics, 23(4), 449477. doi:10.1080/16081625.2015.1017590

Wei, D. J. W. F. F. (2007). A Study on the Relationship between College Students' Emotion Management Ability and Their Mental Health [J]. Chinese Journal of Special Education, 9.

Yung, K., \& Chen, C. (2018). Managerial ability and firm risk-taking behavior. Review of Quantitative Finance and Accounting, 51(4), 1005-1032. doi:10.1007/s11156-0170695-0 